\title{
Accounting for not-for-profit organizations (NFPs) to prevent terrorist financing
}

\author{
Fuminobu Mizutani $\mathrm{a}^{*}$ \\ a College of Business Administration, Kanto Gakuin University, Yokohama, Japan. \\ ${ }^{*}$ Corresponding author's email address: fuminobu@kanto-gakuin.ac.jp
}

\begin{abstract}
A R T I C LE I N F O
Received: 03-03-2017

Accepted: 28-03-2017

Available online: 04-04-2017

Keywords:

Amutot;

Foreign state entity;

Market mechanism;

Pigovian tax;

A B S T R A C T

This paper adopts a text mining approach to determine the concepts and operating process surrounding 'Amutot law ${ }^{1}$ ', for proposing a regulatory basis to account for financial flows of NFPs in U.S.A. Text mining result reveals that financial flows of charitable organizations can be monitored by making these NFPs to provide accurate information on contributions from foreign state entity and using accountants to monitor the nature of donations received by the organizations. Since Amutot law operates under market mechanisms, U.S government can gain substantial leverage to monitor terrorist financing channeled through various NFPs. This will also help protect the freedom to make contributions of American from diverse religious background.
\end{abstract}

Text mining.

JEL Classification :

H56; L31; M41; M42; M48.

(C) 2017 The Authors. This is an open access article under the terms of the Creative Commons Attribution License 4.0, which allows use, distribution and reproduction in any medium, provided the original work is properly cited.

DOI: http://dx.doi.org/10.18533/jefs.v5i02.282

\section{Introduction}

Not-for-profit organizations (NFPs) can serve public interests, if they are properly managed. However, NFPs are sometimes abused by such as terrorists. In the U.S., the case of Holy Land Foundation for Relief and Development (HLF) was a large scandal. HLF was a large Islamic charitable organization. In this scandal, Hamas, an organization based in Palestinian territory, abused HLF for financing. As a result, HLF was shut down by the federal government (Clarke, 2015).

Terrorist financing through NFPs are a problem for police organizations and the Federal Bureau of Investigation (FBI) thinks that the solution to prevent terrorist financing is related to accounting. This belief is supported by Ford, who said in his speech to the American Institute of Certified Public Accountants (AICPA) (Ford, 2007):

We also investigate charities or non-governmental organizations that fraudulently obtain charitable donations and then divert them to support terrorism. This was the case with the Benevolence International Foundation case in Chicago, which was a front for al Qaeda. The executive director pled guilty to racketeering conspiracy and is now serving 11 years in federal prison.

\footnotetext{
1 Amutot is a regulatory document to account the financial flow of NFPs in Israel.
} 
The US Department of Treasury (Treasury) published the second edition of Anti-Terrorist Financing Guidelines in 2005. A section of Anti-Terrorist Financing Guidelines is on accounting; for example, budget, financial reporting, and so on. The paragraphs on accounting are not complicated, but simple. The World Bank (2010) document that Nonprofit Organizations and the Combatting of Terrorism Financing points out the limitation of NFPs' obligations, stating "Depending on how it is done, gathering information on a prospective partner can destroy trust and harm a relationship and the cost, both in terms of times and money, can be considerable" (Does de Willebois, 2010, p. 20).

As explained in the next section, the key to prevent terrorist financing in NFPs in the U.S. may be found in Amutot legislation. One purpose of this paper is to aid in crafting a legislation that will protect the freedom of various religious charities to make charitable contributions while ensuring the money does not fall into the hand of 'unwanted users'. Recently (early 2017) an executive order prohibited peaceful Muslims from entering to the U.S. in the pretext of preventing terrorists to enter to the U.S. (Shear and Cooper, 2017). Off course, it is important to protect the homeland from terrorism, but such a legislative order exemplifies a negative outlook and there is a need for protecting Muslims and separate apple from orange. By referring to Amutot regulations, this paper contributes to design a legislation that will allow religious charities in USA to make contribution.

Amutot or Amuta are by nature traditional Jewish charitable organizations which are funded with tzedakah, which are religiously-motivated contributions (Lipman, 2010). Today, there are various types of NFPs, called Amutot. The means of Amutot and Amuta are same. Rasham Ha'amutot, which means "Registrar of Amutot", is a governmental organization that supervises Amutot in Israel. Rasham Ha'amutot published The Proper Management of Amutot in 2010, and The Proper Management of Amutot includes paragraphs on sophisticated accounting to prevent terrorism based on Amutot Law. The paragraphs in the topic named "Donations from a Foreign State Entity" require Amutot to make disclosures on contributions from foreign state entities. Details of contributions from foreign state entities are required to be noted down in financial statements. In The Proper Management of Amutot, foreign entities refers to, foreign government organizations and Palestinian Authority (PA).

A tax code draft which imposes high taxes on contributions which support terrorism passed the Ministerial Committee for Legislation in Israel, though the revised tax code has not been stipulated yet. An Amutot explains that the draft aims to add the subsection "A donation from a foreign state entity will be subjected to a tax rate of $45 \%$, if the goals or conduct of the non-profit organization, or conduct of any member of the board of the nonprofit organization, expressly or implicitly supports one of the following positions: [omission] (e)Supporting the armed struggle of an enemy state or a terrorist organization against the State of Israel." (Association for Civil Rights in Israel, 2013).The Deputy Education Minister said that tax revenues for the government would be used to strengthen the Israel Defense Forces (IDF)2 (Dvorin, 2015).

Taxation is often regarded as a related area of accounting. Even from (a) to (e) of the subsection are related to terrorism at least indirectly, considering the political conditions of Israel (Dershowitz, 2003). In the U.S., police organizations prevent terrorism within the country, while in Israel IDF also prevents terrorism within the country. Because the newly-implemented high taxes reduce contributions that might eventually be detrimental to the public and increases tax revenues for the government, we can make the hypothesis that the new tax is a Pigovian tax (Mankiw, 2012).

The methodology of this paper is text mining and the document as data is The Proper Management of Amutot. Some results revealed by text mining, for example, the fact is revealed that the management of Amutot is government-oriented. A key policy implication of this paper is that the U.S. can utilize market mechanisms to prevent terrorism activities if it adopts regulations that Israel currently has in place.

Section 2 is literature review on terrorist financing. Section 3 is explanation of methodology. Section 4 shows the results of text mining and discusses about the results. Section 5 indicates policy implications from the results of text mining and discussions.

\section{Literature review}

2 Charities that goes to strengthening IDF, generates legitimate concern about the use of disproportional force by IDF. 
Ramaniuk and Haber (2008) strongly suggests that, for anti-terrorism purposes, accountants should take on a gatekeeper role to ensure NFP compliance, and they can make use of their access and exposure to critical and sensitive information about NFPs. Ramaniuk and Haber (2008) can be regarded as a response to Ford's speech.

With regards to Anti-Terrorist Financing Guidelines, Crimm (2004) believes that NFPs might fall under U.S. Code. The evidence cited in Crimm (2004) is Treasury's opinion about sanctions on NFPs which are abused for terrorist financing. Treasury's opinion is that even if a NFP complies only with Anti-Terrorist Financing Guidelines, the NFP may be imposed criminal or civil sanctions.

Warde (2007) criticizes Anti-Terrorist Financing Guidelines. Although Warde (2007) defends HLF and may be biased, the criticism deserves reference. Warde (2007, p. 148) says;
Muslim donors caught in the dragnet and seeking to avoid future harassment repeatedly asked the US Treasury to release lists of acceptable charities. Instead of such lists, the US Treasury issued voluntary guidelines, which were as vague as they were impractical. [omission] Little assurance was given to prospective donors, since following the guidelines did not preclude future legal or regulatory action.

Moreover, CNN reports that the U.S. spends at least 100 billion dollars a year on counter-terrorism efforts (Sahadi, 2015). The source of government organizations' expenditures comes from citizen taxes. Muller (2008) argues about the roles of accounting for anti-terrorism in the Netherlands indicate that a NFP abused by terrorists damages the reputation and credibility of the entire third sector. Preventing terrorist financing is necessary for NFPs to maintain trust from the public. Muller (2008) proposes that the contributors use a "Seal of Approval" from properly accredited institutions for NFPs and that the approval should be accredited whilst taking accounting practices of NFPs into consideration. Muller (2008) allows a prediction that there are regulations which can be references for the U.S. in other countries. In this connection, the accounting standards for NFPs in the U.K. where the political conditions are similar with the U.S. do not include paragraphs related to prevent terrorism (Charity Commission and Office of Scottish Charity Regulator, 2015).

A country which meets two conditions are desirable for reference. One condition is that the country is an OECD member, like the U.S. The other condition is that terrorist activities are rampant in the country, unlike the U.S. The Netherlands, unfortunately, does not meet the second condition. However, Israel meets both conditions. There is also a similarity between the U.S. and the Israel that NFPs occupy large percentages of GDPs (IsraelGives, 2017), though the political conditions are different between the U.S. and Israel. Thus, we can theorize that the key to prevent terrorist financing in NFPs in the U.S. may be found in Israeli regulations.

Muller (2008) acknowledges that Internal Revenue Service (IRS) collects ample information from NFPs, especially Form 990, a type of typical accounting information. However, Muller (2008) questions whether the IRS has enough personnel to check the accuracy of the information provided. There are some differences in literature above.

\section{Data and methodology}

This paper adopts text mining as the research method. Text mining is a statistical method that analysis documents in a way explained in The New York Times (Guernsey, 2003). This paper adopts the KH Coder Ver. 2 text mining software, because this version of the software is stable. To analysis documents using KH Coder, the document data must be in text format. Thus, this paper uses a text file that has been converted from a PHD file. A few errors occurred during the conversion, which is unavoidable. The purpose of this text mining is to find out what concepts the Israeli government has put in place as the basis of regulations on management of Amutot, including accounting itself and taxation.

The document title which is processed by this software is The Proper Management of Amutot and which was published by Rasham Ha'amutot. Although this data is large, text mining can analysis large documents. The words which do not show particularities of the documents, ex. to, from, and for, are not objective of this text mining. This paper firstly examines the ranking of the frequency of usage of each word. Next, the paper discusses the results of co-occurrence analysis. In co-occurrence analysis, strong relationships are displayed with thick lines, while weak relationships are displayed with thin lines, and words in large circles refer to frequently used words. In Graph 1, each module which consists of related words is colored differently from other modules.

As explained in the next section, the ranking of frequency and the results of co-occurrence analysis reveal two key categories; audit and government. This paper finally analyses the frequency that each category appears in each chapter. The category of audit consists of 3 words; audit, auditor, and accountant. The category of government 
consists of 5 words, Registrar, government, governmental, law, and Law. In Graph 2, the percentages refer to that of the paragraphs each category appears in. The larger the square, the more frequently each category appears in the chapter.

In practicing text mining, many words which does not effects to the analysis appear, for example board, executive, and member. However, it is an unavoidable particularity of text mining.

\section{Results and discussion}

The result of the frequency of usage of each word is shown in Table 1. Table 1 shows the 10 most frequentlyappeared words. AMUTA and AMUTOT have same meaning.

Table1: Ranking

\begin{tabular}{llr}
\hline Ranking & Word & Frequency \\
\hline 1 & AMUTA & 631 \\
2 & Board & 194 \\
3 & Executive & 194 \\
4 & AMUTOT & 139 \\
5 & Audit & 131 \\
6 & member & 122 \\
7 & REGISTRAR & 111 \\
8 & law & 109 \\
9 & General & 108 \\
10 & Committee & 105 \\
\hline
\end{tabular}

"Audit" does not appear in any chapter titles. However, "Audit" is ranked 5th, so we know that it is significant. "Registrar", most of which are Rasham Ha'amutot, is ranked 7th. The word "law", which is related to government organizations, is ranked 8th. This analysis reveals that they are important words in The Proper Management of Amutot. The Proper Management of Amutot also references bookkeepers and controllers. However, the Israeli Government does not want to rely on them, but rather on accountants. It is in accordance with Ford's speech and Ramaniuk and Haber (2008). The result of the co-occurrence analysis is shown in Graph 1.

\section{Graph 1: Co-occurrence}

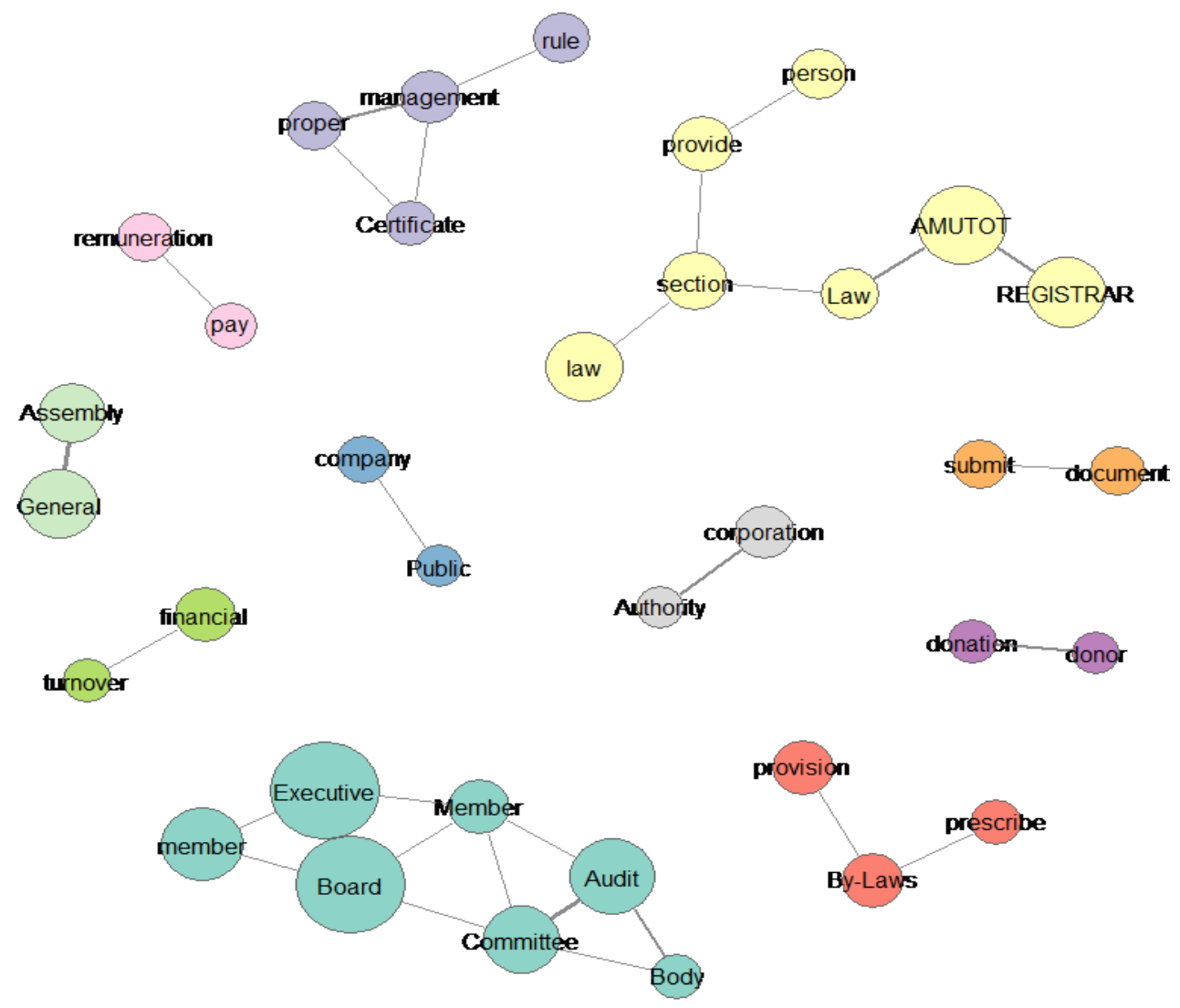


It is revealed that Amutot has strong relationships with Registrar and law, though most modules do not bring findings for this paper because of a particularity of text mining. The meaning of law and Law are the same, though the initials are different. Together with the result of the ranking of frequency, we can know that the government is also important. These relationships indicate that the Israeli government intends the management of Amutot to be government-oriented. That accords with an indication by Crimm (2004) about the US Treasury in some extent. In economics, there is a premise that the fundamental roles of the government are police activities and national defense, from night watch states to welfare states. Thus, Amutot have terrorism prevention measures put in place.

We can know that the Israeli government hopes for one thing from accountants, and that one thing is that accountants guarantee accuracy of financial reporting to contributors. If accurate financial reporting on contributions from foreign state entities are provided, Amutot would not be monitored by government organizations like the IRS but by each contributor. Contributors who support public interests benefit when Amutot are prevented from being used for purposes detrimental to the public. Because this way work contributors' incentives, this is a way to work the market of donation. If the government organizations utilize market mechanism, the problem pointed out by Muller (2008) would be solved.

The result of the third examination is shown in Graph 2.

Graph 2: Appearances in each chapter

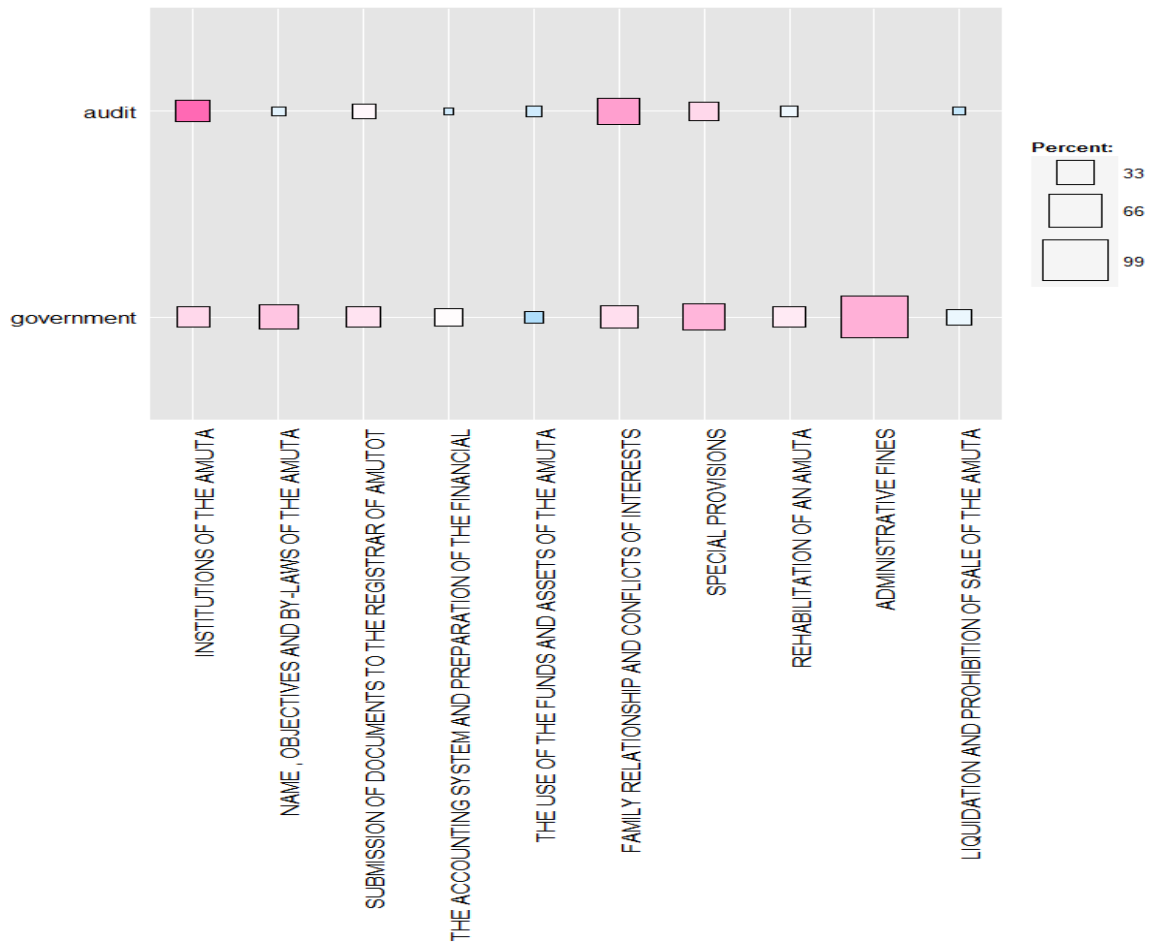

Both the concepts "audit" and "government" appear in various chapters. That means that audit and the government are related to various aspects of Amutot management. Thus, we can judge that auditors are endorsed to be gatekeepers of Amutot in Israel, and we can assume that the Israeli government aims to give incentives to Amutot to avoid receiving contributions that are detrimental to the public through taxation as a form of management. Based on the combined results of the second and third examinations, the concept which the Israeli government has put in place as a basis of regulations is revealed and the hypothesis that the new, high tax is a Pigoyian one can be verified.

\section{Conclusion and policy implications}

Through these three examinations, we can correctly interpret regulations on Amutot. The regulations in Israel can apply to NFPs in the U.S. and help the U.S. government organizations to prevent terrorism activities. The idea that regulations allow NFPs to become aware of government organizations can apply to the U.S., though governmentoriented ones cannot apply to the U.S.

If the U.S. introduces a regulation that requires NFPs to make disclosures about contributions from foreign state entities like in Israel, some problems would be solved. Because not by a particular NFPs but by the government, 
trust with partners will not be destroyed different from the afraid of World Bank. Because it would become easy for contributors, including Muslim Americans, to acquire information about NFPs, the problem pointed out by Warde (2007) that Muslim Americans cannot make contributions safely would be eliminated. Moreover, accountants are endorsed as gatekeepers. The problem of the lack of IRS personnel would be rectified, if the federal government has each contributor monitor NFPs. If the U.S. imposes a Pigovian tax on contributions that are at risk of being used to support terrorism activities, like what the Israeli government is doing, the cost problem reported by CNN would be solved. Both regulations utilize market mechanisms, and the American economic system is a market economy. Thus, these regulations in Israel are suitable for the U.S.

\section{References}

Association for Civil Rights in Israel, (2013). The Amutot (Non-Profit Organizations) Law. Knesset Articles. http://www.acri.org.il/en/knesset/amutot-law/ (accessed 2017)

Aufhauser D., Gerber S, (Jan. 27, 2017). Stop American Aid to the Palestinians until the Terror Ceases. The Wall Street Journal.

Charity Commission, Office of the Scottish Charity Regulator, (2015). Accounting and Reporting by Charities: Statement of Recommended Practice Applicable to Charities Preparing their Accounts in accordance with the Financial Reporting Standard Applicable in the UK and Republic of Ireland.

Clarke CP, (2015). Terrorism, Inc.: The Financing of Terrorism, Insurgency, and Irregular Warfare. Santa Barbara, CL: ABC-CLIO.

Crimm NJ, (2004). High Alert: The Governments War on the Financing of Terrorism and its Implications for Donors, Domestic Charitable Organizations, and Global Philanthropy. William \& Mary Law Review, 45: 1341-1451.

Dershowitz A, (2003). The Case for Israel. Hoboken, NJ: John Wiley \& Sons.

Does de Willebois E, (2010). Nonprofit Organizations and the Combatting of Terrorism Financing: A Proportionate Reseponse. Washington DC: World Bank. https://doi.org/10.1596/978-0-8213-8547-0

Dvorin T, (Dec. 13, 2015). Ministers Approve Tax on Anti-Israel NGOs; Livni to Appeal. Arutz Sheva.

Ford JL, (Sep. 27, 2007). Forensic Accounting and White-Color Crime. Speeches-FBI. https://archives.fbi.gov/archives/news/speeches/forensic-accounting-and-white-collar-crime (accessed 2017).

Guernsey L, (Oct. 16, 2003). Digging for Nuggets of Wisdom. The New York Times.

IsraelGives, (2017). Israel's Amutot. http://www.israelgives.org/information (accessed 2017).

Lipman S, (Oct. 12, 2010). For the Perplexed, a Guide to Giving. The New York Jewish Week.

Mankiw G, (2012). Principles of Economics, 6th edition. Mason, OH: South-Western Cengage Learning.

Muller WH, (2008). Charities and Anti-Money Laundering: Is a "Seal of Approval" the Answer. Trusts \& Trustees, 14(5): 259-271. https://doi.org/10.1093/tandt/ttn028

Naurath N, (Aug 2, 2011). Most Muslim Americans See No Justification for Violence. Gallap.

Romaniuk P., Haber J., (2008). Charities and Terrorist Financing. The CPA Journal, 78(3): 48-50.

Sahadi J, (Nov. 16, 2015). The Cost of Fighting Terrorism. CNN Money.

Schriber AA, Gross AG, Bielawsky AS, (eds.) (2010). The Proper Management of Amutot (Non-Profit Associations). Jerusalem: Registrar of Amutot.

Schuessler J, (Jan. 7, 2017). Modern Language Association Moves to Reject Academic Boycott of Israel. The New York Times.

Shear MD, Cooper H (Jan. 27, 2017). Trump Bars Refugees and Citizens of 7 Muslim Countries. The New York Times. Treasury, (2005). Anti-Terrorist Financing Guidelines: Voluntary Best Practices Guideline for U.S.-Based Charities, Revised Edition. Washington DC: Treasury.

Warde I, (2007). The Price of Fear: The Truth behind the Financial War on Terror. Berkeley, LA: University of California Press. 